\title{
The Research and Practice of Operating Mechanism for College Teachers Teaching Development Centre
}

\author{
Changyu Li \\ Changchun Institute of Technology Changchun 130012 \\ 494106544@qq.com
}

Keywords: Teachers Development Centre; Teacher's development; Improve teaching level

\begin{abstract}
In this article, the basic theories on teaching development among college teachers have been researched, and the concepts, nature and functions related college teachers development have been gradually explored. The basic concept and features of self-development, organization development, active development, passive development, and the relationships between them have been clarified. The current status of College Teachers Teaching Development Centers in China has been analyzed. With the experiences in the overseas developed countries, a set of operating mechanism suitable to China's actual situation has been constituted for college teachers teaching development centers, and finally to improve teaching level and teaching quality among teachers.
\end{abstract}

\section{Introduction}

College teachers development in China has been increasingly paid attention. In 2011, both The Ministry of Education and The Ministry of Finance have pointed in "The Opinions on the Implementation of 'Undergraduate Teaching Quality and Teaching Reform Project during the Twelfth Five-year"' that Teaching development Centre should be actively encouraged to establish for all colleges and universities according to their own characteristics to enhance the ability of university teachers, and a number of college teaching demonstration centers should be established as the focus. At present, Xiamen University, Beijing University of Aeronautics and Astronautics, Shanghai Jiao tong University, Beijing Normal University, Nanjing Normal University, Jilin University and other colleges and universities have established Teacher Development Centers, and have begun to carry out teachers teaching development work [1].

The Construction of operating mode on College Teachers Development Center in line with China's actual work is necessary to solve the lack of university teachers' development work in the past from the practical level. The teachers "passive training" has been changed into "active development" and the teachers' personal development has been combined with organizational development. [2] Teacher training, teaching reform, research the development of teachers exchange teaching quality assessment, teaching and consulting services, in practice, constantly improve teaching development center run university teachers, and effectively improve teaching ability and level.

The Tasks of college teachers development center: First, to sort out the teachers training process from "passive training" to "active development" in promoting teachers teaching development, training, and to combine organically "personal development" with "organizational development"; Secondly, to provide a platform related education and services for all university teachers; again, to constitute an operating mechanism for College Teachers Teaching Development Centre and making it systematic and institutionalized and professional; Finally, to promote the construction of university teaching to a higher goal. Teacher quality is the core assurance of college education quality. Through the research and practice to teachers teaching development center, to urge College Teachers Teaching Development Centre to become promoters of teaching reform, organizer of research and communication, executer of quality assessment, and provider for consulting services and in order to provide a service platform for teachers' lifelong learning [3-5].

The work of Teachers Development Center can be from the following aspects: First to grasp the development dimension of teaching based on their own colleges and universities, studying and 
learning from the domestic and overseas teachers teaching development experience, to constitute teachers teaching development system, to explore and summarize the nature, function and responsibility of College Teachers Teaching Development Centre [6]; to study the situation of college teachers teaching development and identify teachers teaching development projects in College Teachers Teaching development Centre ; to create a "web-based training supermarket" and build a teacher development platform under the network environment; to create a good learning environment and to make teachers have a "consumer" impulse ; to enrich the curriculum resources on the platform for teachers to have optional "goods" [7]; to set up courses in accordance with professional skills and to meet the individual learning needs; to make teachers automatically select courses; to establish a supervisor base with professional teachers and to provide teachers one to one guidance, information consultation and targeted special services [8]. To promote the development of teachers teaching capability, and to further enhance the quality of classroom teaching and talent training; to build virtual class under reality environment. Before the young teachers stepping to the stage, the supervisors will guide each of them by all-round, three-dimensional and full-class coaching so as to enhance youth teachers' teacher level and overall quality as soon as possible. By running this mechanism summing up experience, and spreading among large number of colleges and universities; the security conditions for teacher development center effective running have been analyzed, the topic on how to achieve effective functioning of the teachers development center in practice has been studied, an effective operational mechanism (ideal model) for College Teachers Teaching Development Centre has been build to ensure College Teachers Teaching Development Centre in organized, institutionalized, systematic operation [9].

The running of Teachers Teaching Development Centre should around the topic of "Research and Practice of the Operating Mechanism for College Teachers Teaching Development Centre" and with the combination of vertical, horizontal, point, surface binding. The college teacher teaching development studies in China from basic theory, situation analysis, model construction and practical operation should be start in the following aspects:

First, the basic theory for college teachers teaching development should be studied to explore the concept, nature and function of teachers teaching development, clarify the basic concept, basic features and the relationships between personal development, organizational development, selfdevelopment and passive development. Secondly, the current situation for College Teachers Teaching Development Centre should be analyzed. The mainly analyzing contents for College Teachers Teaching Center should include the evolution, basic mode, objectives, content, organization, functioning mechanisms and so on to analyze the basic trend of college teachers teaching development center and the characteristics of college teachers. Thirdly, the operating mechanism for College Teachers Teaching development Centre (ideal model) suitable to the actual situation in China should be constituted with the experiences of developed countries to explore its security conditions, to meet the needs of university teachers personalized and professional development, and to meet the needs of talent training features. Finally, the teacher's development platform should be established to carry out some actual and effective work related to teacher's development such as teachers training, teaching reform, research and communication, teaching quality assessment, teaching and consulting services, and so on to help teachers to improve their teaching capability.

The operating Mechanism for College Teachers Teaching Development Centre should be carried out by following aspects: to search for and sort of many reference materials domestic and overseas related to teachers teaching development, and to grasp the overall context and history origin of college teachers teaching development to understand its basic course; to study the foreign advanced teaching development theory and practice, and make a comparative analysis with the situation in China to establish an operating mechanism for college teachers teaching center suitable for the actual teachers development in China; to carry out empirical research, that is to promote the improvement of teachers teaching capability through specific teachers development projects; to design teaching evaluation questionnaire to start peer evaluation and evaluation by students for some of the participating teachers in teachers teaching development projects in order to understand 
the improving situation for teachers' teaching level and teaching capability; to draw out interview outline, and to understand teaching development requirements [10].

The establishment for college teachers development platform is to realize the systematic, institutionalized and professional operation for college teachers teaching development and to further enhance teachers' teaching capability and teaching quality. The established platform is to provide some services for each college and universities teachers related to teaching, to encourage teachers to integrate educational technology and teaching. Some related training courses for teachers can be set up and some relevant personal guidance can be provided to create an active academic atmosphere in supporting teachers as educators, scholars, and team-work cooperators.

\section{Acknowledgement}

Jilin Education Science "The Twelfth Five-Year Plan" Project "The Research on Relationships between Teachers Motivation and Educational Quality "( project approval No: GH12213)

Jilin Social Science Fund Project: "The Research on Relationships among Teacher Motivation, Efficacy and Quality of Education" (project approval No: 2012B250)

Jilin Province Educational Science Planning Key Project "The Research and Practice of College Teachers Teaching Development Centre Operational Mechanism" (project approval No: GH2013087)

\section{References}

[1] Ernest Boyle, "The Academic Level Reflection - Professor Working Focus Areas [M] The Motivation and Trend of Education Reform in Developed Countries: Episode 5, Beijing: People's Education Press, 1994.

[2] W. Chen, "From Shelter to Cover: Teaching Academic Development System Analysis" [J]. Higher Education Exploration .2010 (4): 75.

[3] P.J. Guan, "Colleges Teachers Training and Evaluation - the Second part of China New Era College Teachers Training”, [J] China higher education .2001 (Z1):. 38-39.

[4] Y.Jiang, "The Concept and Practice of Japanese College Teachers Development", [J] Peking University Education Review, 2011 (7): 41.

[5] J.Lin, "The Organization Course and Institution of American University Teachers Development", [J] Tsinghua University Education Research, 2010 (4): 49.

[6] M.Y.Pan, "The Development of College Teachers and Enhance to Education Quality", [J] Shenzhen University: Humanities and Social Sciences, 2007 (24): 24.

[7] X.Z. Lu, Higher Education Introduction [M] Shanghai: Higher Education Press, 2009.

[8] D.L.Yue, "The Teaching Style Professor should be Designed in Teachers Title Assessment Suggested by CPPCC Members in Zhejiang Province [EB / OL] // [2012-03-15] (2007-01-29) http // News xinhuanct con / local / 2007-01 / 29 / content5669872. htm

[9] J.P. Wang, "The Reasonable Adjustment to the Value Orientation of Teacher Policy in China", [J] Teacher Education Research. 2005 (6): 6.

[10] X.H.Wang, "University Teachers' Development Policy in China after 1980s", [J] Teacher Education Research, 2007 (1): 43. 